\title{
Dyeing of Jute Fabrics with Prodigiosin Produced from Sago Waste and their Applications
}

\author{
Shanmugam Abirami $\mathbb{D}$, Sudalaimani Dinesh Kumar ${ }^{(D)}$ and Athiappan Murugan* \\ Department of Microbiology, Periyar University, Salem - 636 011, Tamil Nadu, India.
}

\begin{abstract}
Synthetic dyes are hazardous to the environment and humans due to their toxic and recalcitrant nature. Hence, the present study attempts to produce eco-friendly dye from the sago industrial waste using $S$. marcescens SS1. The dye produced by the bacterial bioconversion of sago was characterized by GC-MS and obtained 13.423 acquisition time, which is similar to the standard prodigiosin. The effects of the dyeing parameters were optimized for Jute fabric using tannic acid as a pre mordant, the maximum uptake of dye was observed at $80^{\circ} \mathrm{C}, \mathrm{pH} \mathrm{7,60}$ mins with the $\mathrm{K} / \mathrm{S}$ of 6.6. The minimum $\mathrm{K} / \mathrm{S}$ value of 3.9 was observed at $65^{\circ} \mathrm{C}, \mathrm{pH} 3$ in $45 \mathrm{~min}$. Better colour fastness was observed in prodigiosin with mordant compared to without mordant. The antimicrobial activity of dyed fabric was tested against a few pathogenic bacteria and it showed maximum activity against $P$. aeruginosa. The dye extracted from S. marcescens SS1 prodigiosin was found to be an effective dyeing agent and also pose antimicrobial properties.
\end{abstract}

Keywords: Serratia marcescens SS1, Jute fabric, Prodigiosin, Colour fastness, Antimicrobial activity

(C) The Author(s) 2022. Open Access. This article is distributed under the terms of the Creative Commons Attribution 4.0 International License which permits unrestricted use, sharing, distribution, and reproduction in any medium, provided you give appropriate credit to the original author(s) and the source, provide a link to the Creative Commons license, and indicate if changes were made. 


\section{INTRODUCTION}

In ancient times people used only natural dyes for many purposes such as to colour wool, cotton, and silk fibres. The natural dye was also used to dye leather, fur, and cosmetic items ink, colouring agents, and paints. The natural dye consumption was reduced after the introduction of synthetic dye by Perkin in 1856., Synthetic dyes are stable to light and heat but can cause environmental pollution. ${ }^{3}$ Synthetic dyes discharged from the industries are known to cause a very detrimental to the environment and other living creatures. So nowadays people are looking again for natural dye because natural dyes had environmental compatibility, comparatively less toxicity and zero allergic reaction. Natural dyes are produced by numerous ways such as bacteria, fungi, insects, and plants. ${ }^{4}$

Dyeing of jute fabric has become important since jute is utilized in all types of fabric ranging from attractive value-added textiles to packaging materials. Additionally, since jute fabric is eco-friendly and biodegradable in nature, the demand for jute fabric is increasing globally on a daily basis., ${ }^{5,6}$ While it has many benefits, some drawbacks are also present in jute fabric due to its poor fastness property after dyeing. So, there are several approaches that have been conducted to explain the fundamentals of jute natural coloring along with increasing their fastness, ${ }^{7,8}$ especially the washing and fastness, with numerous metal mordants using as a trial study, a small work has been done with the combination of bio-mordant and chemical mordants. The various metal salts are pre-mordanted onto the jute cloth prior to the dyeing process to increase the colour output and fastness characteristics. ${ }^{9}$ Repetitive treatment with dual mordants, a bio mordant and an eco-friendly synthetic mordant, resulted in an additional improvement in fastness characteristics. The repetitive mordanting resulted in a significant increase in color yield. The increased colour intensity and fastness characteristics are important for optimizing natural colouring and producing as little effluent as possible. The purpose of the present research is to improve the uptake of the dye in jute fabric by using pre mordant method. For this reason, natural mordant tannic acid was used with prodigiosin, the colour fastness and antimicrobial activity would bring additional properties to the dyeing agent used.

\section{MATERIALS AND METHODS \\ Bacterial cultures}

Serratia marcescens SS1 strain received from the Department of Microbiology, Periyar University, Salem, India was used in this study. The bacterial strains have been previously reported and deposited in GenBank (Accession No. MK342495). Staphylococcus aureus, Escherichia coli, Pseudomonas aeruginosa, Enterococcus faecalis and Klebsiella pneumoniae used in the antibacterial test were received from the Department of Microbiology, Periyar University, Salem, India.

\section{Textile material}

The jute fabric bought from the textile market Tirupur, Tamil Nadu, India scoured and bleached before it was used for dyeing studies (weight $110.9 \mathrm{~g} / \mathrm{m}^{2}$; warp density 135 with thickness $0.28 \mathrm{~mm}$ ).

\section{Microbial production of prodigiosin}

The bacterial culture was inoculated in a medium containing Peptone $(5 \mathrm{~g} / \mathrm{L}), \mathrm{NaCl}(5 \mathrm{~g} / \mathrm{L})$, beef extract $(1.5 \mathrm{~g} / \mathrm{L})$ and yeast extract $(1.5 \mathrm{~g} / \mathrm{L})$ was incubated at $25^{\circ} \mathrm{C}$ for 24 hours. Bacterial inoculum $(1 \mathrm{ml})$ cultured for 24 hours was inoculated into a fermentation broth containing $\mathrm{NH}_{4} \mathrm{Cl}, \mathrm{K}_{2} \mathrm{HPO}_{4}$, $\mathrm{KH}_{2} \mathrm{PO}_{4}, \mathrm{MgSO}_{4}, \mathrm{FeSO}_{4}, \mathrm{CoCl}_{2}, \mathrm{MnCl}_{2}, \mathrm{CaCl}_{2}$, $\mathrm{NH}_{4} \mathrm{Mo}_{7} \mathrm{O}_{24}$, and 1.5 percentage of sago waste as carbon source. The seeded broth was incubated at $25{ }^{\circ} \mathrm{C}$ for $72 \mathrm{~h}$. Prodigiosin produced in the fermentation broth was extracted by centrifuging at $10000 \mathrm{rpm}$, for $10 \mathrm{mins}$ at $4{ }^{\circ} \mathrm{C}$. The supernatant of the fermented broth was removed and the pellet was dissolved with acidified methanol (v/v). ${ }^{10}$ After that, the sample was centrifuged and the supernatant was dried and stored for the further dyeing process.

\section{Gas chromatography and mass spectrometry analysis}

Gas chromatography analysis was performed using a Mass Spectrometer: 7000 Triple Quad (Agilent, US), equipped with a Column DB17 MS (30mm $0.32 \mathrm{~mm}$ ID $0.25 \mathrm{~m}$, composed of $95 \%$ methyl polysiloxane and $5 \%$ phenyl), helium with a flow rate of $1.8 \mathrm{ml} / \mathrm{min}$ at $250^{\circ} \mathrm{C}$. At $70 \mathrm{eV}$, electron impact mode is used. The oven temperature was 
set to rise from $50{ }^{\circ} \mathrm{C}$ (isothermal for 1.0 minute), at a rate of $30^{\circ} \mathrm{C} / \mathrm{min}$ to $210^{\circ} \mathrm{C}$ (isothermal for 1.0 minute and with an increase of $7^{\circ} \mathrm{C} / \mathrm{min}$ to $310^{\circ} \mathrm{C}$ isothermal for 3.0 minute. Detected peaks were compared with standard prodigiosin (Enzo life science, USA). The $(0.25 \mathrm{mg})$ standard prodigiosin was dissolved in $1 \mathrm{~mL}$ methanol and serially diluted for quantification.

\section{Mordanting Procedure}

Mordant baths were prepared by using 10 percent tannic acid to render a fabric using a pre-mordant process. Mordanting of jute fabric began at room temperature by maintaining the ratio of substance to liquid ratio at 1:20. After the mordant baths were completed, the fabric sample was removed and dyed.

\section{Dyeing jute fabric with prodigiosin}

The dyeing process was done by using a rota dyer machine (Rossari lab tech, Mumbai). The dyeability of jute fabric by the prodigiosin extract, dyeing was carried out with and without mordanting processes. After removing the jute fabric sample from the dyeing machine, it was cold washed and soaped with $1 \mathrm{~g} / \mathrm{L}$ non-ionic soap. The dyed cloth was dried at $85^{\circ} \mathrm{C}$ for 20 minutes before being rinsed with cold water.

\section{Characterization of colour characteristic}

The dyed fabric and color intensity were calibrated using DC International's Spectra flash ${ }^{\circledR}$ SF 300. The calibrated value is referred to as the $\mathrm{K} / \mathrm{S}$ value. The values for dyed cloths are also measured in aspects of the CIELAB colour space $\left(L, a, b, c^{*}\right.$, and $\left.h^{*}\right)$, where a denotes colour red-green, $b$ denotes colour yellow-blue, $\mathrm{L}$ denotes luminosity from light to dark, $c^{*}$ denotes saturation, and $h *$ denotes metric hue angle, using the Gretag Macbeth 7000 eye system (USA).

\section{Colour fastness test}

The standard method was used to test the fastness properties of dyed jute fabric. The Rubbing ISO-105-X12, washing ISO 105-C10 and perspiration fastness ISO AATCC 105- E04 were to be tested.

\section{Response surface methodology (RSM)}

The experimental design, statistical evaluation, drawing of response surface plots, and optimization of the variable factors of the dyeing factors were done by Design Expert 7.0 software, using Response Surface Technique (RSM) and Box-Behnken design. ${ }^{11}$ The design of experiments consisted of 17 runs for three variables and three levels $(-1,0$, and +1$)$, with $A, B$, and $C$ referring to temperature, $\mathrm{pH}$, and time, respectively (Table 1 ). The data attained from experiments were analysed by a polynomial quadratic model.

Antibacterial activity of prodigiosin

The bacterial inoculums such as Staphylococcus aureus, Escherichia coli, Pseudomonas aeruginosa, Enterococcus faecalis and Klebsiella pneumoniae were used to validate the antibacterial properties of the dyed fabric. Overnight cultures were spread over Muller Hinton agar plates using sterile swabs. After dyeing, the dyed sample was cut into small parts and placed into the agar plates before the washing procedure. For 24 hours, the setups described above were incubated at $37{ }^{\circ} \mathrm{C}$. The zone of inhibition was detected on the agar plates, indicating the prodigiosin dye's inhibitory action.

Table 1. Response surface methodology factors and their levels

\begin{tabular}{lcccc}
\hline Factor & Description & $\begin{array}{c}\text { Level 1 } \\
(-1)\end{array}$ & $\begin{array}{c}\text { Level 2 } \\
(0)\end{array}$ & $\begin{array}{c}\text { Level 3 } \\
(+1)\end{array}$ \\
\hline $\mathrm{A}$ & Temp. $\left({ }^{\circ} \mathrm{C}\right)$ & 65 & 80 & 95 \\
$\mathrm{~B}$ & $\mathrm{pH}$ & 3 & 5 & 7 \\
$\mathrm{C}$ & Time (mins) & 30 & 45 & 60 \\
\hline
\end{tabular}

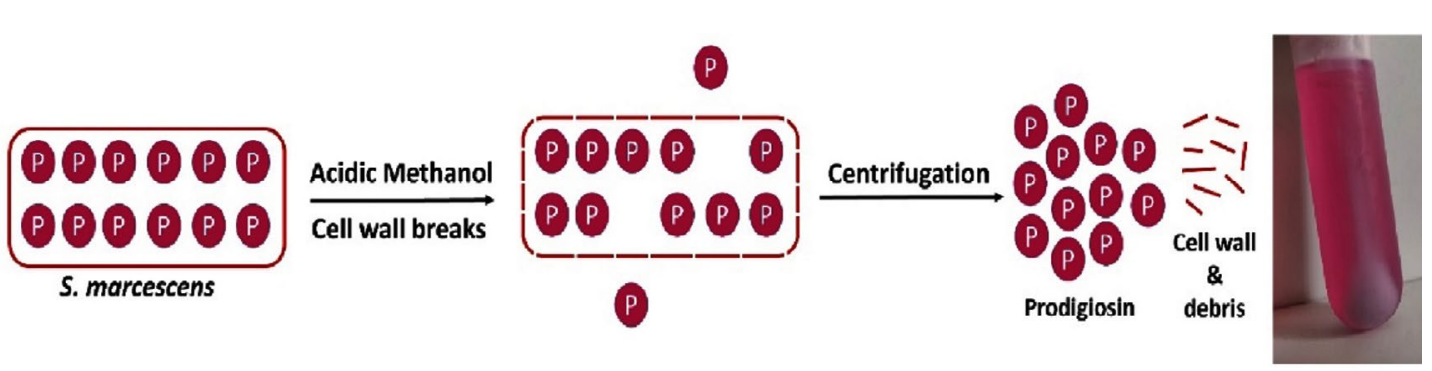

Fig. 1. Extraction process of prodigiosin dye from Serratia marcescens SS1 using acidified methanol 


\section{RESULTS AND DISCUSSIONS Production and preparation of dye}

The prodigiosin was produced from $S$. marcescens SS1 by using sago waste as substrate. Prodigiosin is a secondary metabolite, mostly it is produced as an intracellular pigment which was extracted by using an acidified methanol. The role of acidified methanol is to break the bacterial membrane and destroy the cell wall by which the prodigiosin can be extracted out (Fig. 1). The acidified methanol fraction containing prodigiosin is vaccumized and powdered. Similarly, there are few attempts were made to produce prodigiosin from low-cost waste materials like cassava liquid waste, corn steep and demineralized crab shell powder. ${ }^{12,13}$

Characterization and quantification of the extracted dye

After extraction, the prodigiosin was characterized and quantified based on the peak area of total ion count (TIC). Fig. 2A shows the TIC and acquisition time (13.425) of the standard prodigiosin, Fig. 2B shows the TIC of dye extracted from $S$. marcescens SS1, and the $\mathrm{m} / \mathrm{z}$ ratio characteristic for each ion was analysed in GC-MS. The peak (13.423) obtained for the test sample was similar to the standard prodigiosin. The relative mass spectra analysis confirms the presence of prodigiosin molecules. S. marcescens SS1 produced $44.6 \mathrm{mg} / \mathrm{L}$ of prodigiosin by using sago waste as substrate.

\section{Effect of mordant on dyeing of jute fabric}

Prodigiosin was used for the dyeing of jute fabric and colour strength was measured by CIELab colour coordinates. The $\mathrm{K} / \mathrm{S}$ values obtained for dyeing jute cloth with and without mordant are listed in Table 2. The results indicate that jute cloth pre-mordanted with tannic acid and prodigiosin had the maximum dye absorption value of 5.57 $\mathrm{K} / \mathrm{S}$, compared to $4.37 \mathrm{~K} / \mathrm{S}$ for unmordanted fabrics. The result obtained with tannic acid pre mordant improves dyeing quality and high colour yield. ${ }^{14}$

$\mathbf{A}$

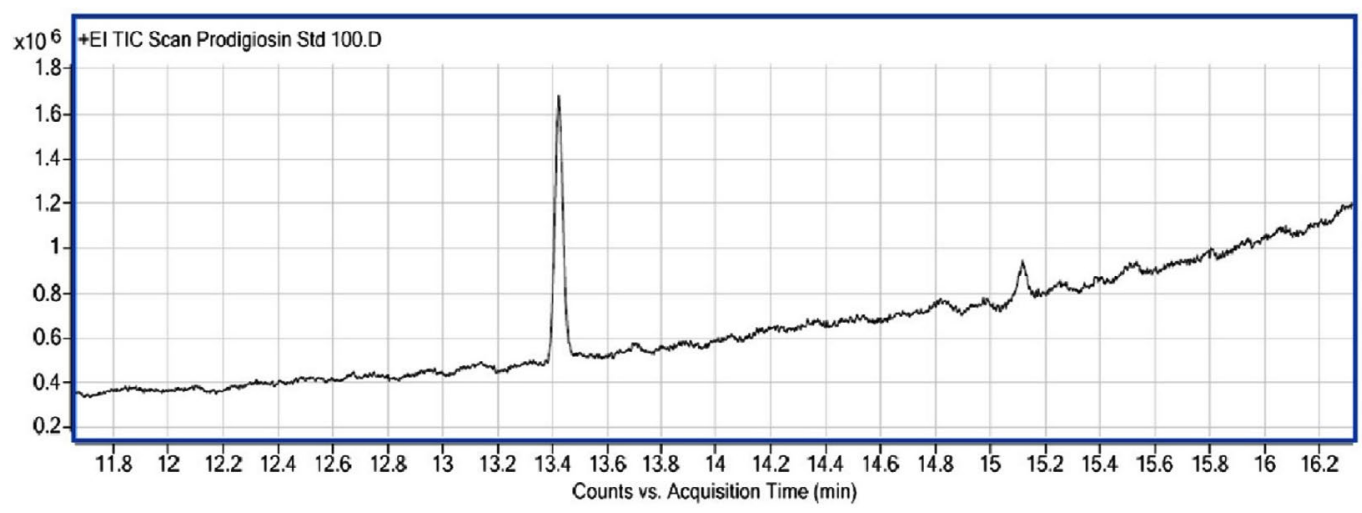

B

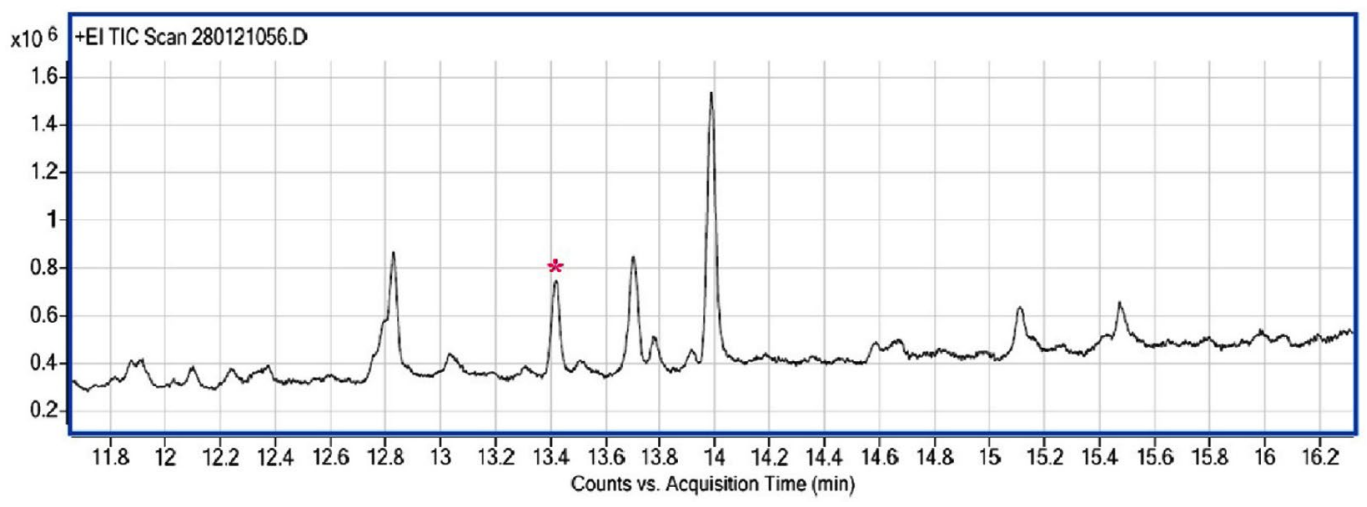

Fig. 2. GC-MS analysis of standard prodigiosin (A) and prodigiosin dye extracted from Serratia marcescens SS1(B). 
Box-Behnken experimental design and analysis of variance

For a better dyeing process, the response surface methodology was used to optimize different factors like dyeing time, temperature and $\mathrm{pH}$. The experimental response was calculated as $\mathrm{K} / \mathrm{S}$ value. In order to optimize dyeing, seventeen experiments were designed using the Box Behnken Design, and their values were displayed in Table 3. At experiment 12 , a maximum $\mathrm{K} / \mathrm{S}$ value of 6.6 was recorded, whereas, at experiment 15 , a minimum $\mathrm{K} / \mathrm{S}$ value of 3.9 was noted.

Lignin and hemicelluloses content of jute fibre exhibit $\mathrm{COOH}$ positively contribute enhance colouring. ${ }^{14}$ Lower temperatures result in a larger adsorption rate, and vice versa, according to a dyeing optimization study. The bonds between adsorbate dye molecules and the adsorbent binding site decrease while increasing the temperature. This could be why the adsorption phenomena works better at lower temperatures. The maximum dye absorption was obtained with reactive orange 14 is $80^{\circ} \mathrm{C}$. This is most likely due to Reactive Orange 14 dye molecular structure and molecular weight. ${ }^{15} \mathrm{~A}$ dyeing temperature of $80^{\circ} \mathrm{C}$ was the best dyeing condition. studied the dyeing of bleached jute fabric for both Lemon Yellow and Red CN dyes. ${ }^{16}$

The $\mathrm{pH}$ has a significant impact on the ionization and the qualities of the jute fabric.

Table 2. Effect of mordant in dyeing of jute fabric

\begin{tabular}{|c|c|c|c|c|c|c|c|}
\hline Dyeing & $\begin{array}{l}\text { Apparent } \\
\text { Colour }\end{array}$ & $\mathrm{K} / \mathrm{S}$ Value & L & a & $b$ & C & $\mathrm{h}$ \\
\hline $\begin{array}{l}\text { Tannic acid (10\%, } \\
\% \text { Shade) }\end{array}$ & & 4.04 & 77.52 & 1.77 & 16.26 & 16.35 & 83.77 \\
\hline $\begin{array}{l}\text { Prodigiosin Without } \\
\text { Mordant }\end{array}$ & & 4.37 & 67.82 & 15.56 & 7.74 & 13.38 & 26.45 \\
\hline $\begin{array}{l}\text { Prodigiosin With } \\
\text { Mordant }\end{array}$ & & 5.57 & 59.66 & 10.28 & 8.09 & 13.08 & 38.19 \\
\hline
\end{tabular}

Table 3. Response surface methodology calculated factors, their levels and comparison of experimental and predicted response ( $\mathrm{K} / \mathrm{S}$ value) in $\mathrm{BB}$ design

\begin{tabular}{lcccc}
\hline Run & $\begin{array}{c}\text { Temp. } \\
{ }^{\circ} \mathrm{C}\end{array}$ & $\mathrm{pH}$ & $\begin{array}{c}\text { Time } \\
\text { (mins) }\end{array}$ & $\begin{array}{c}\mathrm{K} / \mathrm{S} \\
\text { value }\end{array}$ \\
\hline 1 & 80 & 5 & 45 & 5.6 \\
2 & 80 & 3 & 60 & 5.8 \\
3 & 80 & 5 & 45 & 5.5 \\
4 & 65 & 5 & 30 & 4.1 \\
5 & 95 & 5 & 60 & 6.2 \\
6 & 65 & 5 & 60 & 5.7 \\
7 & 65 & 7 & 45 & 5.6 \\
8 & 80 & 5 & 45 & 5.7 \\
9 & 80 & 7 & 30 & 5.4 \\
10 & 80 & 3 & 30 & 4.2 \\
11 & 95 & 5 & 30 & 5.2 \\
12 & 80 & 7 & 60 & 6.6 \\
13 & 80 & 5 & 45 & 5.5 \\
14 & 95 & 7 & 45 & 6.1 \\
15 & 65 & 3 & 45 & 3.9 \\
16 & 80 & 5 & 45 & 5.6 \\
17 & 95 & 3 & 45 & 5.1
\end{tabular}

As a result, the adsorption process was altered, and the responsiveness to $\mathrm{pH}$ variations was varied as well. It was discovered that while increasing $\mathrm{pH}$, the $\mathrm{Q}$ max (maximum sorption capacity) also increase as well. ${ }^{17}$ The reason for this is that the rate of adsorption increases as the $\mathrm{pH}$ of the dye solution increases. This is due to the eventual deprotonation of the adsorbent functional groups, which increases the attraction by charge transport between dye cations and negatively charged sites on the jute fabric. And at lower $\mathrm{pH}$ values, the functional groups on the jute fabric undergo protonation, causing the jute fabric to become positively charged, resulting in a decrease in adsorption between dye and ion due to electrostatic repulse. ${ }^{18}$ The dye solution is extracted and used to dye bleached jute fabric in three distinct media: alkaline, acidic, and neutral. The natural dyes Annatto, Ratanjot, Babool, and Manjistha were next tested for dye adsorption. Babool and Manjistha offer the finest results in 
terms of neutral conditions. Babool has the highest $\mathrm{K} / \mathrm{S}$ value when compared to the other four dyes. ${ }^{19}$

For Basic Violet 14, dyeing time is favourable, where $\mathrm{K} / \mathrm{S}$ value attains maximum with a further rise after 60 min of dyeing time. ${ }^{15}$

The findings of this study are comparable to those of previous studies that used Prodigiosin and other plant extracts to fabric. ${ }^{20}$ achieved optimal silk dyeing with prodigiosin isolated from Zooshikella rubidus at $60^{\circ} \mathrm{C}$ for 60 minutes at $\mathrm{pH}$ 4.0 in their investigation. ${ }^{21}$ Found that dyeing with prodigiosin suspension derived from S. marcescens on cellulosic cloth worked best when done at 90 ${ }^{\circ} \mathrm{C}$ for 90 minutes. Prodigiosin suspension was also tested in polyester and acrylic fabrics. According to, ${ }^{21,22}$ the finest dyeing outcomes were achieved at $110{ }^{\circ} \mathrm{C}$ for 30 minutes at 7.4 and $100{ }^{\circ} \mathrm{C}$ for 30 minutes at 7.4. Mango plant source was employed as a substrate for dyeing cotton fabric in ${ }^{23}$ research. The result obtained from the response surface methodology experiments were evaluated for the absorption of the dye. An experimental relationship between the response ( $\mathrm{K} / \mathrm{S}$ value) and independent variables was stated by the following model:

$\mathrm{K} / \mathrm{S}$ value $=+5.58+0.4125 * \mathrm{~A}+0.5875$

$* B+0.675 * C-0.175 * A B-0.15 * A C-0.1 * B C$ $-0.3025 * A 2-0.1025 * B 2+0.0225 * C 2$

Where $A, B$, and $C$ are the operational variables' coded values for temperature, $\mathrm{pH}$, and time, respectively.

Table 4 illustrates the model of a secondorder polynomial equation using analysis of variance (ANOVA). The F-test ANOVA is used
A

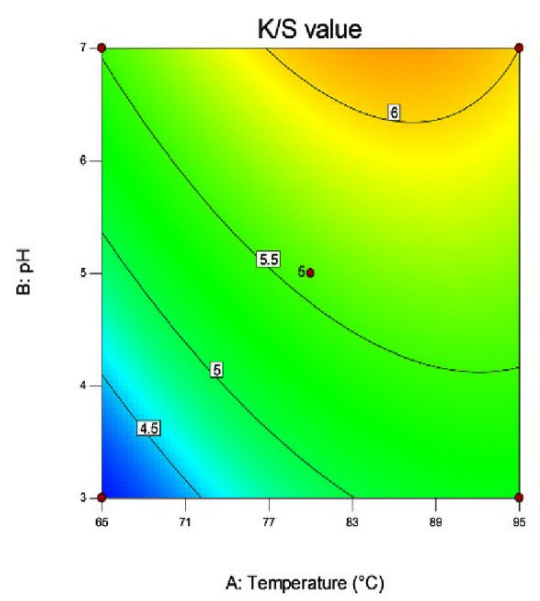

B

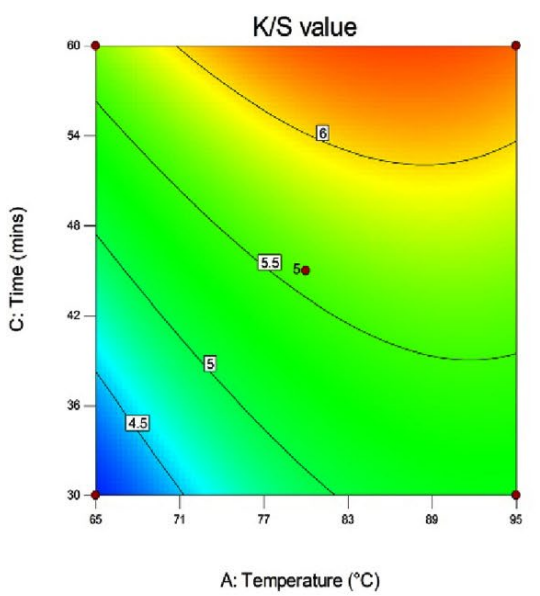

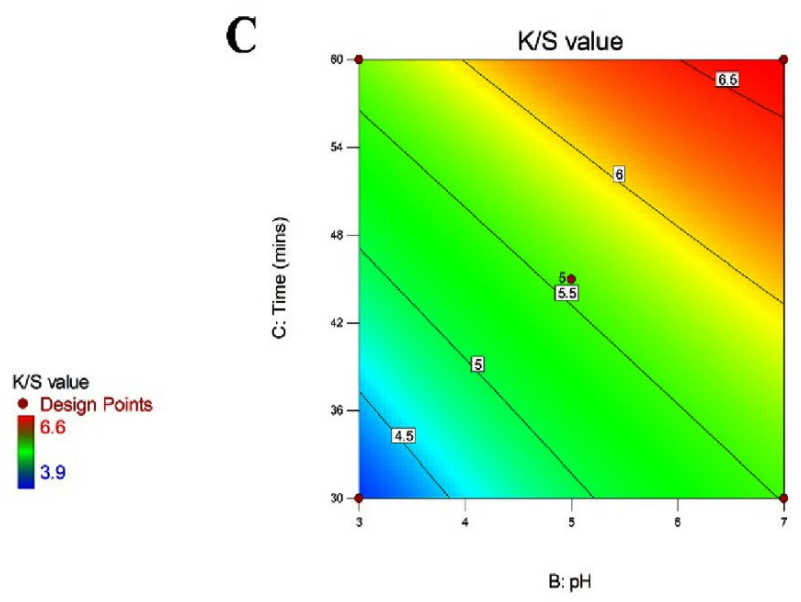

Fig. 3. Contour plot of dyeing efficiency ( $\mathrm{K} / \mathrm{S}$ value) showing an interaction between temperature, $\mathrm{pH}$ and time. 
to determine the model equation's statistical significance. The significance of each coefficient was determined using F- and P-values. The F-value (68.94) with $\mathrm{P}<0.0001$ indicates that the regression model is significant, and there is only a 0.03 percent chance that such a large F-value occurs due to noise. The regression analysis of the ANOVA model determined that the $\mathrm{R} 2$ value was 0.9888 and that the adj. 0.9745 as the R2 value. This indicates that the model adequately accounts for 98.88 percent of the variation observed in the experimental data.

Table 4 demonstrates that all three variables are statistically significant, with dyeing time having the highest F-value (267.17), pH having the second highest F-value (202.4), and temperature having the lowest F-value (99.78). From this result, dyeing time and $\mathrm{pH}$ has more influence on the dyeing process. The interaction impact of dyeing temperature and $\mathrm{pH}$ has a $p$-value of 0.02 and the interaction effect of dyeing temperature and time has a p-value of 0.0371 , indicating that the interaction is statistically significant. The interaction between dyeing time and $\mathrm{pH}$ has a $\mathrm{p}$-value of 0.13 , so it is statistically insignificant.

\section{Optimization and validation of dyeing condition in jute fabric by a statistical approach}

The contour plots for the interactions of $A B, A C$, and $B C$ are given in Fig. 3, and the contour plots have been extended to provide more information on the interaction effects of the

Table 4. ANOVA for Response Surface Quadratic Model

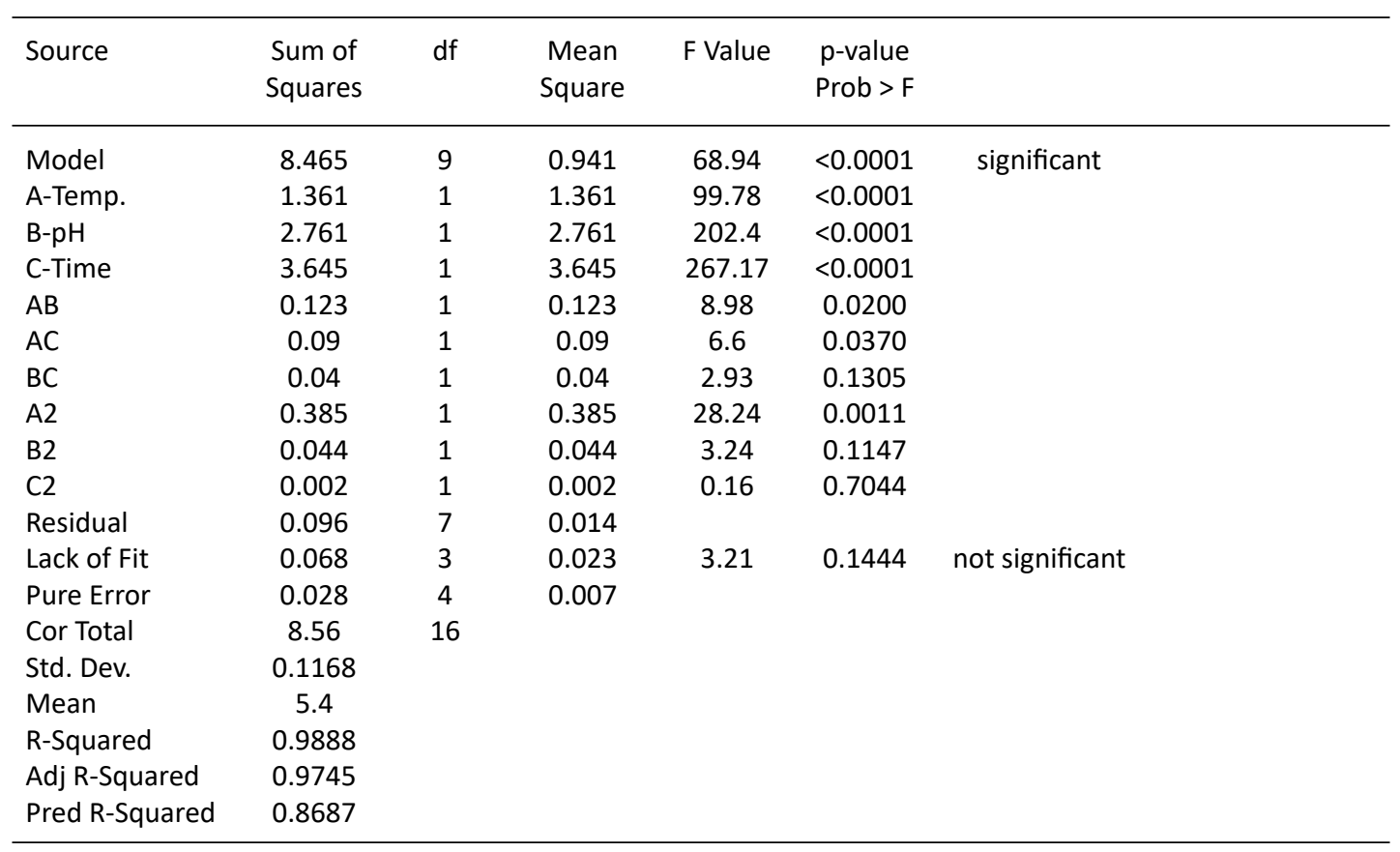

Table 5. BBD model verification of prodigiosin dyeing parameter for jute fabric

\begin{tabular}{lcc}
\hline Parameters & $\begin{array}{c}\text { Predicted } \\
\text { value }\end{array}$ & $\begin{array}{c}\text { Experimental } \\
\text { value }\end{array}$ \\
\hline Temp. ${ }^{\circ} \mathrm{C}$ & 88.2 & 88.2 \\
$\mathrm{pH}$ & 6.4 & 6.4 \\
Time & 68.2 & 68.2 \\
$\mathrm{~K} / \mathrm{S}$ value & 6.49 & 6.52
\end{tabular}

factors on the response. In the result maximum The plot's red area denotes the highest $\mathrm{K} / \mathrm{S}$ value, while the blue region denotes the lowest $K / S$ value. Fig. 3A illustrates the combined impact of $\mathrm{pH}$ and temperature, demonstrating that raising the $\mathrm{K} / \mathrm{S}$ value from $\mathrm{pH} 5$ to 7 and concurrently increasing the maximum $\mathrm{K} / \mathrm{S}$ value from 80 to $95{ }^{\circ} \mathrm{C}$ were observed. The combined impact of time and temperature is shown in Fig. 3B, with the figure 
indicating that the $\mathrm{K} / \mathrm{S}$ value red after 50 minutes at $80^{\circ} \mathrm{C}$. Fig. $3 \mathrm{C}$ illustrates the combined impact of $\mathrm{pH}$ and time, indicating that a neutral $\mathrm{pH}$ of 7.0 and a time interval of 60 minutes have an influence on the $\mathrm{K} / \mathrm{S}$ value.

Multiple response optimization was used to optimize dyeing conditions in jute cloth, with combinations of all three factors examined in this study, and desirability can be evaluated by changing the values of input parameters. Validation was performed on the experiment with the maximum desirability of the optimized sample. The predicted and experimental results obtained using the maximum desirability are shown in Table 5. As expected, the predicted and experimental values for the responses of the optimized parameters with the maximum desirability are almost identical. As a result, it may be stated that the relevant empirical model equations for jute cloth dyeing are valid.

\section{Colour fastness test of dyed jute fabric}

The colour fastness test with mordant and without mordant was shown in Table 6 . In dry fastness both with mordant and without mordant gives (4-5) good results. But in wet fastness with mordant gives 4-5 value and without mordant gives 4 , it is less compared to with mordant. In washing, fastness was the value was low 2 \& 1 in both mordant without mordant and it indicates considerably change was found. In Perspiration fastness, change in colour was checked in both alkaline and acidic conditions. In with mordant 4-5 value was obtained but value 4 obtained without mordant. This result indicates tannic acid is natural mordant and prodigiosin gave good rubbing fastness and perspiration fastness. However, the washing fastness on jute fabric with prodigiosin has still need to be improved.

Antibacterial activity of prodigiosin Prodigiosin has good antimicrobial

Table 6. Colour Fastness for dyed Jute fabric

\begin{tabular}{lcc}
\hline Parameters & $\begin{array}{c}\text { Prodigiosin } \\
\text { without mordant }\end{array}$ & $\begin{array}{c}\text { Prodigiosin } \\
\text { with mordant }\end{array}$ \\
\hline Dry Rubbing fastness & $4-5$ & $4-5$ \\
Wet Rubbing fastness & 4 & $4-5$ \\
Washing fastness Change in colour & 1 & 2 \\
Acidic Perspiration fastness Change in colour & 4 & $4-5$ \\
Alkaline Perspiration fastness Change in colour & 4 & $4-5$ \\
\hline
\end{tabular}

\section{Antimicrobial Activity}

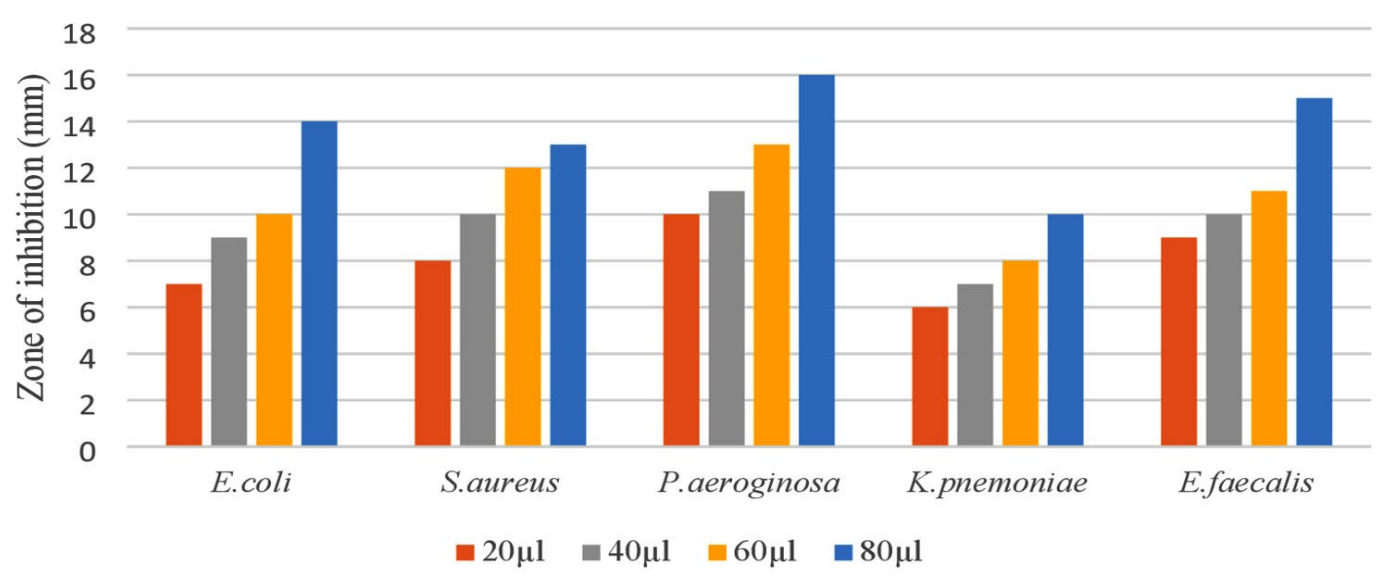

Fig. 4. Antibacterial activity of prodigiosin dye extracted from S. marcescens SS1 against E. coli, S.aureus, P.aeruginosa, K.pneumoniae, E.faecalis. 
properties against various bacteria. ${ }^{24-26}$ To ascertain the colored jute fabric's antibacterial properties, five bacterial strains mentioned above were used and the results were shown in the Fig. 4. Among these, The maximum zone of inhibition was observed with P.aeroginosa when it was prodigiosin. A similar research was conducted against $E$. coli and $S$. aureus, with an estimated bacteriostatic rate of $51.43 \%$ and $94.12 \%$ against E. coli and S. aureus, respectively. ${ }^{27}$

\section{CONCLUSION}

The present study shows that dyeing of jute with prodigiosin and tannic acid can appreciably enhance the uptake of dye by the jute fibre. According to Box Behnken Design temperature $80^{\circ} \mathrm{C}, \mathrm{pH} \mathrm{7.0}$, and 60 minutes gave better dye intake with the $\mathrm{K} / \mathrm{S}$ value of 6.6. The colour fastness tests of dyed fabrics against rubbing and perspiration test have an acceptable range of good to excellent, However, the washing fastness gives a poor result. The dyed jute fabric has good antimicrobial activity against pathogenic organisms. Hence these results suggest, that the sago waste can be used for the production of prodigiosin. The dye produced from $S$. marcescens SS1, found to be suitable dyeing.

\section{ACKNOWLEDGMENTS}

The authors acknowledge DST -FIST [SR/FST/LSI -640/2015(c) Dt.30/05/2016] for the instrumental support. The authors would like to thank Periyar University, Salem for Periyar University Research Fellowship.

\section{CONFLICTS OF INTEREST}

The authors declare that there is no conflict of interest.

\section{AUTHORS' CONTRIBUTION}

All authors listed have made a substantial, direct and intellectual contribution to the work, and approved it for publication.

\section{FUNDING}

None.

\section{DATA AVAILABILITY}

All datasets generated or analyzed during this study are included in the manuscript

\section{ETHICS STATEMENT}

This article does not contain any studies with human participants or animals performed by any of the authors.

\section{REFERENCES}

1. Lee DK, Cho DH, Lee JH, Shin HY. Fabrication of nontoxic natural dye from sappan wood. Korean Journal of Chemical Engineering. 2008;25(2):354-358. doi: 10.1007/s11814-008-0058-6

2. Mirjalili M, Nazarpoor K, Karimi L. Eco-friendly dyeing of wool using natural dye from weld as co-partner with synthetic dye. Journal of Cleaner Production. 2011;19(9-10):1045-1051. doi: 10.1016/j. jclepro.2011.02.001

3. Ngulube T, Gumbo JR, Masindi V, Maity A. An update on synthetic dyes adsorption onto clay based minerals: $A$ state-of-art review. J Environ Manage. 2017;191:35-57. doi: 10.1016/j.jenvman.2016.12.031

4. Mariselvam R, Ranjitsingh A, Selvakumar PM, Krishnamoorthy R, Alshatwi AA. Eco friendly natural dyes from Syzygium cumini (L)(Jambolan) fruit seed endosperm and to preparation of antimicrobial fabric and their washing properties. Fibers and Polymers. 2017;18(3):460-464. doi: 10.1007/s12221-017-1097-6

5. Cai Y, David SK, Pailthorpe MT. Dyeing of jute and jute/ cotton blend fabrics with $2: 1$ pre-metallised dyes. Dyes and Pigments. 2000;45(2):161-168. doi: 10.1016/ S0143-7208(00)00019-X

6. Callow H, Speakman J. The action of light on jute. Journal of the Society of Dyers and Colouristis. 1949;65(12):758-763. doi: 10.1111/j.1478-4408.1949. tb02557.x

7. Samanta AK, Agarwal P, Singhee D, Datta S. Application of single and mixtures of red sandalwood and other natural dyes for dyeing of jute fabric: studies on colour parameters/colour fastness and compatibility. Journal of the Textile Institute. 2009;100(7):565-587. doi: 10.1080/00405000802125246

8. Teli M, Adivarekar R, Bhagat M, Manjrekar S. Response of jute of the dyes of synthetic and natural origin. Journal of the Textile Association. 2002;129:134.

9. Haji A. Improved Natural Dyeing of Cotton by Plasma Treatment and Chitosan Coating. Optimization by Response Surface Methodology. Cellulose Chem Technol. 2017;51(9-10):975-982.

10. Bae J, Moon $\mathrm{H}$, Oh KK, et al. A novel bioreactor with an internal adsorbent for integrated fermentation and recovery of prodigiosin-like pigment produced from Serratia sp KH-95. Biotechnol Lett. 2001;23(16):13151319. doi: 10.1023/A:1010573427080

11. Ferreira SL, Bruns RE, Ferreira HS, et al. Box-Behnken design: an alternative for the optimization of analytical methods. Analytica Chimica Acta. 2007;597(2):179186. doi: 10.1016/j.aca.2007.07.011

Casullo de Araujo HW, Fukushima K, Takaki GMC. Prodigiosin production by Serratia marcescens UCP 1549 using renewable-resources as a low cost substrate. Molecules. 2010;15(10):6931-6940. doi: 10.3390/molecules15106931

13. Nguyen VB, Nguyen DN, Nguyen AD, et al. Utilization 
of Crab Waste for Cost-Effective Bioproduction of Prodigiosin. Marine Drugs. 2020;18(11):523. doi: 10.3390/md18110523

14. Bouatay F, Meksi N, Adeel S, Salah F, Mhenni F. Dyeing Behavior of the Cellulosic and Jute Fibers with Cationic Dyes: Process Development and Optimization Using Statistical Analysis. Journal of Natural Fibers. 2016;13(4):423-436. doi: 10.1080/15440478.2015.1043685

15. Hoque MA, Saiduzzaman M, Faruqui AN, Islam MA. Tenacity and colorfastness properties of chemically modified jute fibres dyed with Reactive Orange 14 and Basic Violet 14. Research Journal of Textile and Apparel. 2016;20(2):102-111. doi: 10.1108/RJTA-10-2015-0030

16. Samanta A, Chakraborty S, Roy TG. Dyeing of jute with reactive dyes: Optimisation of the process variables and assessment of colourfastness characteristics. Journal of The Institution of Engineers (India): Series E. 2012;93(1):15-24. doi: 10.1007/s40034-012-0002-5

17. Hassan MM, Saifullah K. Sustainable dyeing and functionalization of jute fabric with a Chinese sumac gall-derived gallotannin using eco-friendly mordanting agents. Cellulose. 2021;28(8):5055-5070. doi: 10.1007/ s10570-021-03805-x

18. Dey AK, Dey A. Selection of optimal processing condition during removal of Reactive Red 195 by $\mathrm{NaOH}$ treated jute fibre using adsorption. Groundwater for Sustainable Development. 2021;12:100522. doi: 10.1016/j.gsd.2020.100522

19. İsmal OE. Greener natural dyeing pathway using a by-product of olive oil; prina and biomordants. Fibers and Polymers. 2017;18(4):773-785. doi: 10.1007/ s12221-017-6675-0

20. Kim Y, Choi J. Dyeing properties of microbial prodiginine from Zooshikella rubidus for silk fabrics. Fibers and Polymers. 2015;16(9):1981-1987. doi: 10.1007/

\section{s12221-015-5211-3}

21. Ren Y, Gong J, Fu R, et al. Dyeing and antibacterial properties of cotton dyed with prodigiosins nanomicelles produced by microbial fermentation. Dyes and Pigments. 2017;138:147-153. doi: 10.1016/j. dyepig.2016.11.043

22. Ren Y, Fu R, Fang K, et al. Clean dyeing of acrylic fabric by sustainable red bacterial pigment based on nanosuspension system. Journal of Cleaner Production. 2021;281:125295. doi: 10.1016/j.jclepro.2020.125295

23. Ayele M, Tesfaye T, Alemu D, Limeneh M, Sithole B. Natural dyeing of cotton fabric with extracts from mango tree: A step towards sustainable dyeing. Sustainable Chemistry and Pharmacy. 2020;17:100293. doi: 10.1016/j.scp.2020.100293

24. Alihosseini F, Ju KS, Lango J, Hammock BD, Sun G. Antibacterial colorants: Characterization of prodiginines and their applications on textile materials. Biotechnology Progress. 2008;24(3):742-747. doi: 10.1021/bp070481r

25. Gulani C, Bhattacharya S, Das A. Assessment of process parameters influencing the enhanced production of prodigiosin from Serratia marcescens and evaluation of its antimicrobial, antioxidant and dyeing potentials. Malays J Microbiol. 2012;8(2):116-122. doi: 10.21161/ mjm.03612

26. Venil CK, Zakaria ZA, Ahmad WA. Bacterial pigments and their applications. Process Biochemistry. 2013;48(7):1065-1079. doi: 10.1016/j. procbio.2013.06.006

27. Ren Y, Gong J, Fu R, et al. Dyeing and functional properties of polyester fabric dyed with prodigiosins nanomicelles produced by microbial fermentation. Journal of Cleaner Production. 2017;148:375-385. doi: 10.1016/j.jclepro.2017.01.168 